\title{
Increasing the operational stability of running surfaces of aluminothermic welded rail joints by hot grinding
}

\author{
Marina Galay $^{1, *}$ and Eduard Sidorov ${ }^{1}$ \\ ${ }^{1}$ Siberian Transport University, 630049 Novosibirsk, Russia
}

\begin{abstract}
Welded joints have traditionally been a weak point in a design of continuous welded rail (CWR) tracks. Grinding can be used as a resource-saving technology. The purpose of this paper is to study the grinding technology for welded rail joints at different temperatures. The temperature in the weld grinding zone varied from 560 to $850{ }^{\circ} \mathrm{C}$. Using methods of microstructural analysis and hardness measurement, it has been established that different temperature conditions for weld grinding lead to the creation of non-identical mechanical properties of metal and a surface structure of the rail head in the weld zone. As a result of the research, an optimum temperature range, $600 \ldots 560^{\circ} \mathrm{C}$, was determined. This range is recommended for grinding aluminothermic welded joints.
\end{abstract}

\section{Introduction}

At present, contact or aluminothermic welding methods are used to weld rails throughout the railway network $[1,2]$. The strength of aluminothermic rail welds is lower than that of joints welded by contact welding [3]. One of ways to increase the strength of welded rail joints proposed in $[4,5]$ is to modify a thermite powder by titanium or zirconium. It has been shown that the modification decreases grain content in the weld structure. Strength tests of modified welded joints have demonstrated that they have higher wear resistance and contact fatigue than unmodified welds.

Scientists of the Japanese Railway Technical Research Institute have proven that defects in welds and strength reduction are caused by incorrect installation of casting molds on rails prior to aluminothermic welding. They studied effects of the geometry of casting mold installation on filling a welding mold with liquid metal [6].

Papers [7-9] report the results of studies aimed at improving the quality of welded rail joints after welding through normalization and surface plastic deformation. Normalization of welded rail joints provided the best results. It has been established that normalization excludes harmful effects of overheating in the heat-affected zone. However, a problem of implementing the normalization process in real conditions has not been solved yet.

This paper proposes a method for hardening welded rail joints by hot grinding. The purpose of the paper is to study effects from grinding of welded rail joints, which have

* Corresponding author: galayms@mail.ru 
different residual temperatures after aluminothermic welding, on hardness and roughness. It should be noted that aluminothermic welded joints are now ground in two stages: hot grinding (immediately after removing a casting mold and burring) and cold grinding (at a weld temperature of less than $100{ }^{\circ} \mathrm{C}$ ). The regulatory documents that describe the welding process by aluminothermic method [10] do not specify the temperatures at which hot grinding should be carried out. Moreover, a review of literature sources has shown that there is insufficient information on hot grinding of materials [11].

In the context of the current trend towards increasing the length of continuous welded rail tracks all over the world, this study, aimed at improving the operational stability of welded joints, is relevant.

\section{Materials and research methods}

12 samples were prepared for the study. Samples were produced by aluminothermic welding of 0.25 -meter long rails. Rails and a welding thermite consisting of powdered metal aluminum and scales were used as initial welding materials [10].

After the end of the welding process, the samples were burred with hydraulic shears. Then the samples were ground at a different residual post-weld temperature of the weld metal, which varied from 850 to $560{ }^{\circ} \mathrm{C}$. The temperature range $850 \ldots 560{ }^{\circ} \mathrm{C}$ was selected experimentally. A value of $850{ }^{\circ} \mathrm{C}$, which was recorded immediately after burring, was taken as the maximum post-weld temperature of the welded joint. $560{ }^{\circ} \mathrm{C}$ was taken as a lower limit of the temperature range since phase transitions had completed at this temperature. The metal temperature in the weld zone was measured by non-contact method using a Mastech MS6550A digital pyrometer. Samples were ground with an SShG-1 hydraulic grinding machine manufactured by SNAGA at a speed of 3,000 rpm and a cutting depth of $0.2 \mathrm{~mm}$.

To measure the hardness and roughness of running surfaces of a rail weld, templates were cut using a UE-350 SA semi-automatic horizontal band saw machine. The hardness was measured with a HBRV-187.5 multi-purpose hardness tester by Rockwell method described in [12]. An indentation scheme for hardness measurement is shown in Figure 1. The surface roughness was measured with a MarSurf PS1 roughness measuring instrument in accordance with the procedure described in [13]. Microstructural studies were performed using a Carl Zeiss EVO50 microscope.

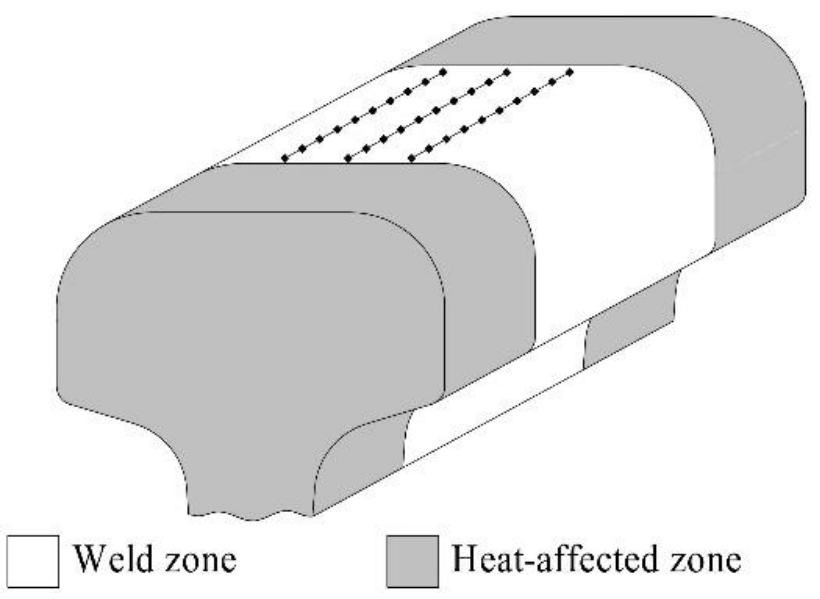

Fig. 1. Scheme of hardness test for welded rail joints. 


\section{Experimental data and results}

Figure 2 shows hardness test results for the samples ground at different residual post-weld temperature of the rail. It should be noted that hardness values of the samples are in a wide range of 24 to $35 \mathrm{HRC}$.

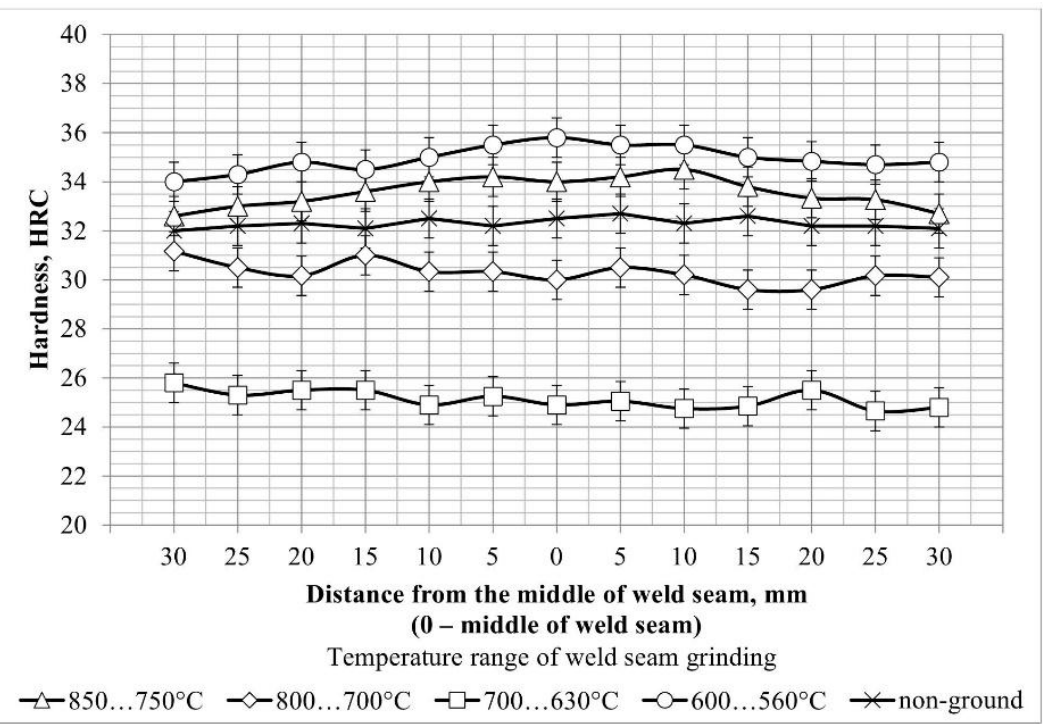

Fig. 2. Weld hardness distribution on the running surface of the rail head after grinding at different residual post-weld temperatures.

The maximum increase in the hardness up to $34 \ldots 36 \mathrm{HRC}$ is observed when a welded joint is ground at a temperature range of 600 to $560{ }^{\circ} \mathrm{C}$. Since the pearlite structure deforms in this temperature range, work hardening is observed [14]. Grinding of welded rail joints in a temperature range of $850 \ldots 750^{\circ} \mathrm{C}$ leads to the effect of high-temperature thermomechanical treatment, which is accompanied by deformation of austenite. However, the deformation of austenite does not persist due to dynamic recrystallization, which results in softening [15]. Therefore, when welded joints are ground in a temperature range $850 \ldots 750^{\circ} \mathrm{C}$, the hardness decreases to $24 \ldots 26 \mathrm{HRC}$. Grinding of welded joints with a temperature of $800^{\circ} \mathrm{C}$ to $630{ }^{\circ} \mathrm{C}$, leads to an increase to $4 \ldots 6 \mathrm{HRC}$ as compared to grinding in a temperature range $850 \ldots 750^{\circ} \mathrm{C}$. A significant increase in the hardness seems to be due to the fact that the deformation is already taking place in the pearlite transformation zone, while the intensity of the dynamic recrystallization process is decreasing.

The microstructure of a weld that has not been mechanically treated during cooling is a cast structure of acicular low-carbon sorbite with ferrite in interdendritic layers (Fig. 3, a). The metal of welds exposed to hot grinding has a different structure (Fig. 3, b-e). Grinding in a temperature range of $850 \ldots 750{ }^{\circ} \mathrm{C}$ led to austenite deformation and, therefore, to the formation of a dispersed sorbitic structure. The exposure of the metal to lower temperatures in a range of $800 \ldots 700{ }^{\circ} \mathrm{C}$ was accompanied by deformation of austenite during its decomposition and the formation of an inhomogeneous microstructure with reduced hardness. Grinding in a temperature range of $700 \ldots 630{ }^{\circ} \mathrm{C}$ led to the formation of an inhomogeneous structure with globular pearlite sections and an increase in hardness as a result of the prevailing hardening process. The weld ground in a temperature range $600 \ldots$ $560{ }^{\circ} \mathrm{C}$ has a ferrite-perlite microstructure with grains stretched through deformation, which is confirmed by work hardening. 


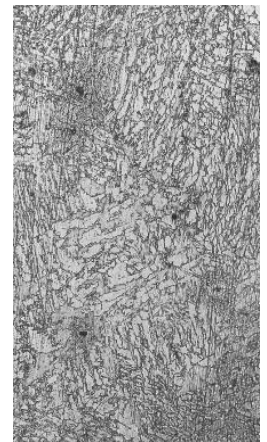

a

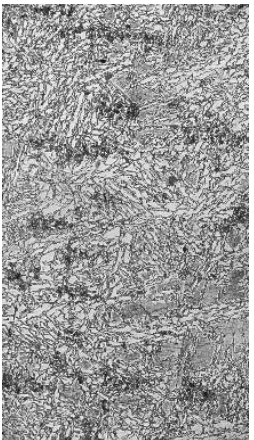

b

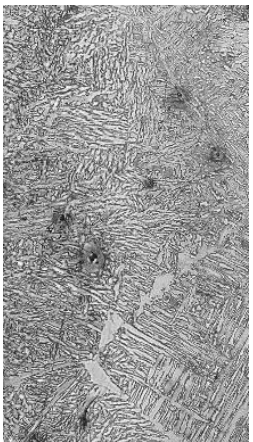

C

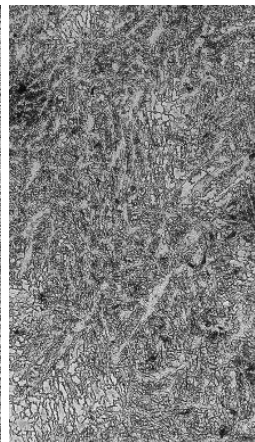

d

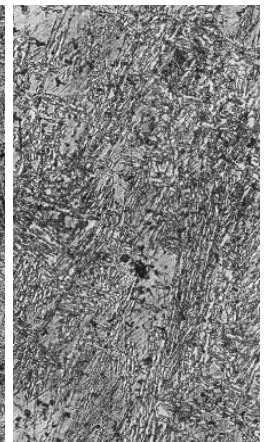

e

Fig. 3. Microstructure of an aluminothermic rail weld: $a$ - without machining; $b$ - after grinding in a temperature range of $850 \ldots 750{ }^{\circ} \mathrm{C}$; $\mathrm{c}$ - after grinding in a temperature range of $800 \ldots 700^{\circ} \mathrm{C} ; \mathrm{d}-$ after grinding in a range of $700 \ldots 630^{\circ} \mathrm{C}$; e - after grinding in the range of $600 \ldots 560{ }^{\circ} \mathrm{C}$.

Effects from grinding of welded rail joints, which have different residual post-weld temperatures, on the surface roughness are presented in Figure 4.

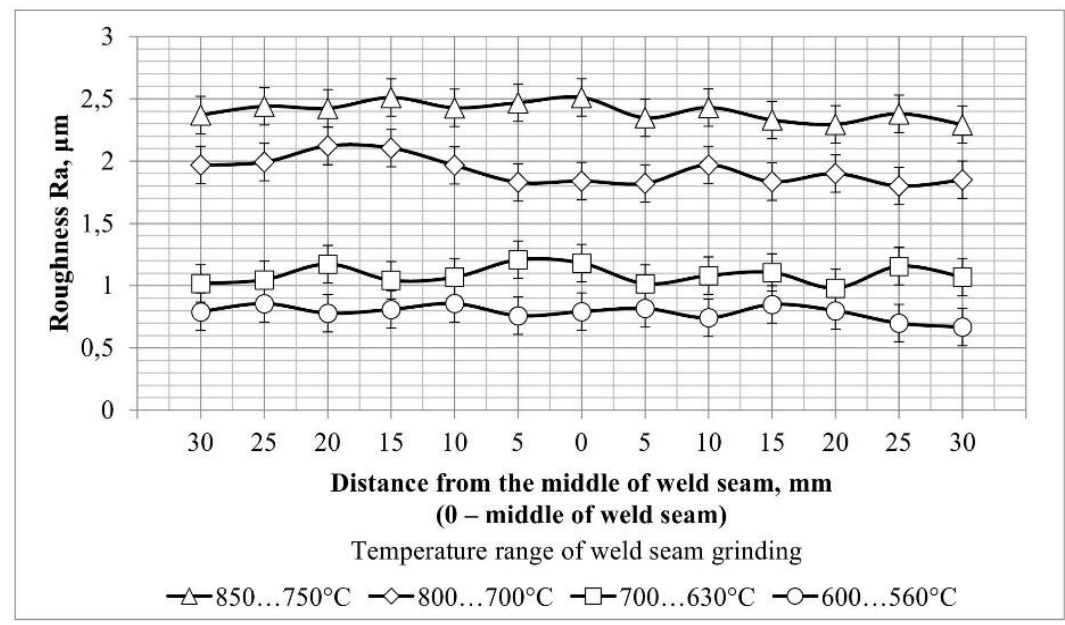

Fig. 4. Weld roughness distribution after grinding at different residual post-weld temperatures.

It can be seen from the graph that roughness values decrease with a decrease in the postweld temperature of the weld. For example, when a welded joint with a residual post-weld temperature of $850 \ldots 750^{\circ} \mathrm{C}$ is ground, the roughness varies from 2.3 to $2.6 \mu \mathrm{m}$. When a welded joint with a residual post-weld temperature of $600 \ldots 560^{\circ} \mathrm{C}$ is ground, the roughness is equal to $0.6 \ldots 0.8 \mu \mathrm{m}$. This is explained by the fact that in a range of $850 \ldots 750{ }^{\circ} \mathrm{C}$, much heat is concentrated in the cutting zone, which leads to significant softening of the metal in the surface layer and increase in the roughness. At grinding temperatures of $600 \ldots 560^{\circ} \mathrm{C}$, the thermal exposure decreases and the surface is deformed to a lesser extent.

\section{Conclusion}

As a result of completed studies, the authors developed a method to harden running surfaces of welded rail joints by grinding the material of the joint zone in hot condition. A 
recommended temperature range of a weld joint for post-weld grinding has been found to be $600 \ldots 560{ }^{\circ} \mathrm{C}$. It has been established that grinding of welded joints with this post-weld temperature provides a hardness level close to that of the base rail metal. Hardening of welds by hot grinding is a promising way to improving post-weld treatment processes for welded joints.

\section{References}

1. N.A. Kozyreva, A.A. Usoltsev, R.E. Kryukov, R.A. Shevchenko, P.E. Shishkin, Innovacii $v$ toplivno-jenergeticheskom komplekse $i$ mashinostroenii [Innovations in the fuel and energy complex and mechanical engineering (TEK - 2017)] Proceedings of the International scientific conference, 123-128 (Kemerovo, Russia, April 18-21, 2017).(in Russian)

2. S.E. Orlov, Railway Track and Facilities, 10, 26-28 (2016). (in Russian)

3. S.E. Aleksentseva, Vestnik of Samara State Technical University. Technical Sciences Series, 1(49), 130-137 (2016). (in Russian)

4. D.M. Costea, M.N. Gảman, G.T. Dumitru, Bulletin of the Transilvania University of Braşov CIBv, Vol. 7(56), Special Iss. 1, 285-288 (2014).

5. M. Brânzei, T. Coman, International Journal of Chemical, Molecular, Nuclear, Materials and Metallurgical Engineering, Vol. 6, 8, 745-748 (2012).

6. R. Yamamoto, Y. Terashita, M. Tatsumi, H. Itoh, K. Umenai, Quarterly Report of RTRI, Vol. 57, 2, 112-117 (2016).

7. V.A. Karguin, L.B. Tikhomirova, M.S. Galay, Ye.S. Kuznetsova, Welding International, Vol. 29, Iss. 2, 155-157 (2015).

8. L.B. Tikhomirova, A.S. Ilinykh, M.S. Galay, E.S. Sidorov, Obrabotka Metallov Metal Working and Material Science, 1(70), 60-66 (2016). (in Russian)

9. V.A. Kargin, L.B. Tikhomirova, A.D. Abramov, M.S. Galai, Welding International, Vol. 28 (3), 245-247 (2014).

10. TU 0921-337-01124323-2016. Railway rails welded in a thermite way. Technical specifications (Moscow, 2016). (in Russian)

11. N.I. Boyko, K.S. Fisenko, Engineering journal of Don, T. 20 (2), $51-55$ (2012). (in Russian)

12. GOST 9013-59. Metals. Method of measuring Rockwell hardness (Moscow, 2001). (in Russian)

13. GOST 2789-73. Surface roughness. Parameters and characteristics (Moscow, 2006). (in Russian)

14. L.M. Kaputkina, M.L. Bershteyn, V.A. Zaymovskiy, Termomehanicheskaja obrabotka stali [Thermomechanical treatment of steel] (Metallurgiya, Moscow, 1983). (in Russian)

15. L.I. Tushinskiy, A.A. Bataev, L.B. Tikhomirova, Struktura perlita i konstruktuivnaja prochnost' stali [Perlite structure and structural strength of steel] (Nauka, Novosibirsk, 1993). (in Russian) 